\section{origniar compundoamoits.}

\section{STATISTICAL REPORT OF CASES OF HERNIA AND LITHOTOMY IN THE RADCLIFFE INFIRMARY, OXFORD.}

By E. L. HUSSEY, Esq., one of the Surgeons to the
Infirmary.

[Continued from page 184.] LITHOTOXY.

THE operations for stone have been noted in the Admission Books from 1816; from which time to 1838, when they are recorded in the Register of Operations, 61 operations were performed on in-patients two of the patients being women. Of the 59 male patients 6 died.

The only particulars I can learn of the cause of death in any case have been obtained through the help of Mr.Hagley, formerly house-surgeon and apothecary to the infirmary; the whole of the surgeons who were attached to the infirmary during the period having died.

CASE I. A man, aged 30 years, gave this history of himself. For some difficulty in micturition, about three weeks before admission, he pushed a radish down the urethra, when part of it broke off, and got into the bladder. After a delay of $t$ welve months, the operation was performed, and some portions of calculous matter deposited on a piece of radish were extracted; two days afterwards a second operation was undertaken by another of the surgeons, the partner of the former operator, for the removal of what it was thought still remained behind. The man died not long after this second operation.

CAsE Ir. A man, aged 34 years, died of scarlet fever. The operation was performed soon after his admission: and it is thought he had been exposed to the contagion before he was admitted.

CAsE IIr. A young man, aged 22 years, died gradually from exhaustion, after the removal of a large calculus from which he had suffered for many years.

The other deaths were in patients of the ages of 17,65 , and 12 years.

Two other cases deserve separate mention:-

CASE IV. A boy, aged 10 years, after remaining twelve months in the infirmary (Sept. 1835 to Sept. 1836), was discharged "relieved". He came under observation again in February 1854, eighteen years after the operation, suffering from a continual slight dribbling of urine from a fistulous passage in the perinæum, the result of the wound in the operation which had never quite healed.

CAsE v. A boy, aged 3 years, underwent operation, when a calculus was not found. Upon a second operation, twelve months afterwards, a calculus was extracted, weighing seventy grains. (6.)

In one case, a man, aged 53 years, three calculi were removed; and in another, a man, aged 60 years, two: both patients recovered.

In the annexed Table, the composition of the calculi is described (in some of the few cases in which they have been preserved) from the Catalogue of the Anatomical Museum in Christ Church. In a separate Table are notes of three cases since the former report: one of these patients died.

CASE vi. A boy, aged 12, died the twenty-sixth day. The calculus was a large flat oral, eight drachms in weight, one inch and fre-eighths in length, one inch and three-eighths in width, and six-eighths of an inch thick. The rectum was wounded in the operation; freces pacsed through the wound from the time of the oporation till his deach. Buppuration was diffused throughout the pelvis; and cae lage collection (about four pints) of matter in the perritonoum was circumseribed among the coinrolutions of the intentines, on the left side of the abdomen, reaching to the diaphrager. (818.)

OAgE VIr. In a man, aged 64, hromorrhage was noticed at the operation proceeding from the orifice of the urethra; and severe heomorrhige from the wound occurred soon after his removal to bed. Two vessels were tied, clearly, as it seemed to me, the divided ends of the artery of the bulb in its normal distribution; as free hæmorrhage continued, the round was plugged, learing an elastic tube in the bladder. The man was rather low for some days, from the loss of blood, but recovered well. (195.)

Cass viII. In one patient under my care, a delicate strumous boy, aged between five and six, the wound was very slow in healing. He passed bloody urine during an attack of scarlet fever when about eighteen months old, and suffered from symptoms of urinary disease from that time; but medical advice was not sought till shortly before his admission into the infirmary. Upon sounding, a calculus was readily detected, always resting in the same direction-that of the left sacro-iliac symphysis. At the operation, the calculus seemed to be held in a cyst of the bladder; and, as I found difficulty in the attempt to dislodge it with forceps, I removed it with the scoop. An abscess formed in the perinæum, and discharged through the wound; the left testis afterwards swelled, and discharged a small quantity of matter through the scrotum. The boy remained three months in the infirmary after the operation. The wound having then closed, he was sent home; but was brought back in a fortnight; his mother reporting that a full stream of urine passed through the perinæum when he empticd the bladder. Finding he had been exposed to the contagion of small-pox, I raccinated him in the arm. The vaccine vesicle rose slowly; the eruption of variola appeared, and the disesse ran its course with some degree of severity. The only treatment, with a view to the closure of the wound in the perinæum, consisted in seeing that the bladder was frequently emptied, night as well as day; the orders given for the purpose being well executed by the nurse. He was discharged after a stay of rather more than three months, during which time I could not discover that a single drop of urine had passed through the perinæum. From what his mother has lately told me, I think the wound must be firmly healed. (220.)

Out of the whole number of 101 operations (37 in the former report and 64 in this), 95 were in the male subject. Of these 95 operations 13 were fatal. None of the 6 female patients died.

The proportion of deaths varies under different operators. In the accompanying Table, the different surgeons are marked by Roman numerals, and the cases, with those in the former report, are thus assigned to them :

II. Sixteen operations.

IV. Thirty-seven operations; eight deaths.

v. Ten operations; three deaths.

vi. Seventeen operations.

Ix. Six operations.

x. Four operations; one death.

xI. Four operations.

The case in which the piece of radish formed the nucleus of a calculus is not included : the original operator is marked 11 and the other VI.

TABLE I.-Cases of Lithotomy from 1810 to 1838.

\begin{tabular}{|c|c|c|c|}
\hline Day of admission. & $\begin{array}{l}\text { Patient's } \\
\text { sex and } \\
\text { age. }\end{array}$ & $\begin{array}{l}\text { Nature of calculus } \\
\text { and duration } \\
\text { of gymptoms. }\end{array}$ & Day of discharge. \\
\hline 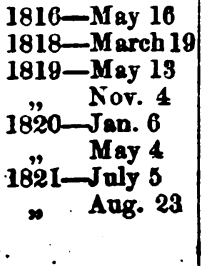 & $\begin{array}{l}\text { M. } 3 \\
\text { M. } 47 \\
\text { M. } 7 \\
\text { M. } 21 \\
\text { M. } 17 \\
\text { M. } 7 \\
\text { M. } 60 \\
\text { M. } 53\end{array}$ & $\begin{array}{lr}2 \text { years } & (\mathrm{II}) \\
3 \text { years } & \text { (VI) } \\
1 \text { jear } & \text { (VI) } \\
6 \text { months } & \text { (II) } \\
\text { Years } & \text { (Iv) } \\
\text { Years } & \text { (V) } \\
4 \text { years } & (\mathrm{VI}) \\
3 \text { calculi; } 2 & \\
\text { Jears } & \text { (v) }\end{array}$ & $\begin{array}{ll}\text { July 18. } & \text { Cured } \\
\text { Aug. 6. } & \text { Cured } \\
\text { July 29. } & \text { Cured } \\
\text { Dec. 3. } & \text { Cured } \\
\text { Feb. 8. } & \text { Died } \\
\text { June 1. } & \text { Cured } \\
\text { Aug. 30. } & \text { Cured } \\
\text { Sept. 27. } & \text { Cured } \\
& \end{array}$ \\
\hline
\end{tabular}




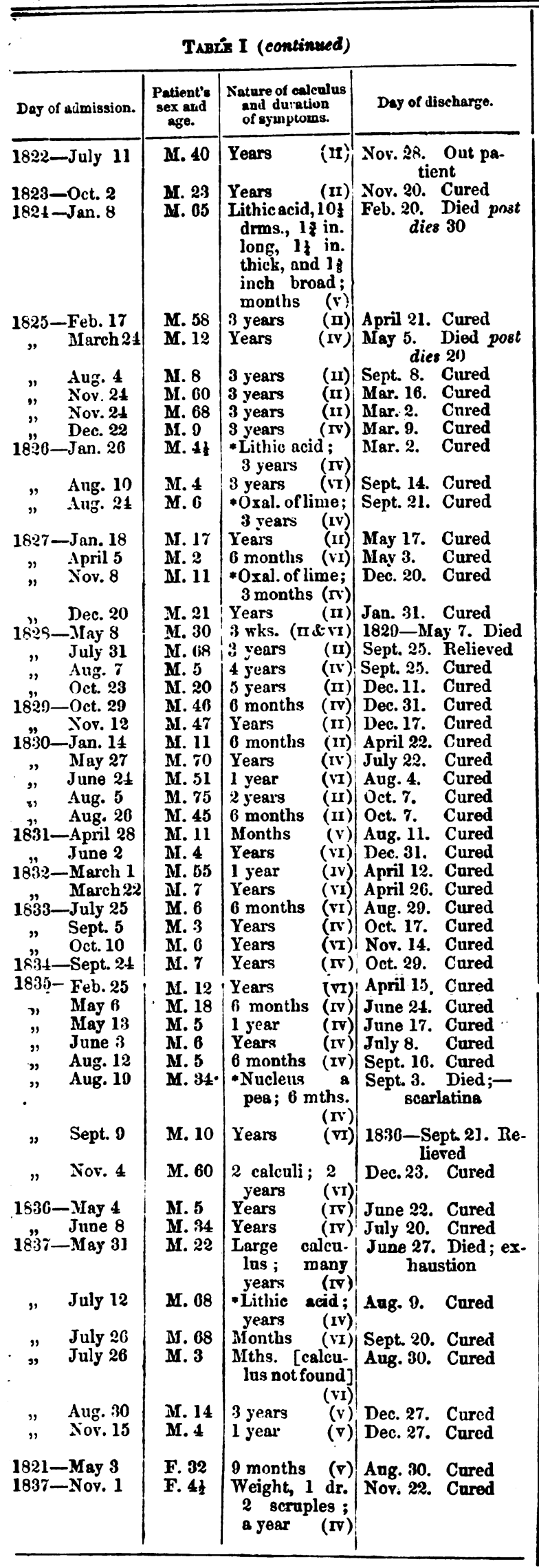

TABIE II.-Cases since the publication of the Report in the Traneactions.

\begin{tabular}{|c|c|c|c|}
\hline Day of operation. & $\begin{array}{l}\text { Patient's } \\
\text { sex aud } \\
\text { age. }\end{array}$ & $\begin{array}{l}\text { Nature of calculus } \\
\text { and dunstion } \\
\text { of 8ymptoms. }\end{array}$ & Day of discharge. \\
\hline $1852-N o v .1$ & $\begin{array}{l}\text { M. } 64 \\
(105)\end{array}$ & $\begin{array}{r}\text { Flat oval, lithic } \\
\text { acid, } 3 \text { drs. } 29 \\
\text { grs.; } 12 \text { mths. }\end{array}$ & Dec. 1. Cured \\
\hline $18 J 4-J a n .30$ & $\begin{array}{l}\text { M. } 12 \\
(212)\end{array}$ & $\begin{array}{l}\text { Lithic acid and } \\
\text { lithate of am- } \\
\text { monia, } 8 \mathrm{drs} . \\
4 \text { years }\end{array}$ & Feb. $24 . \underset{\text { xitonitis }}{\text { Died ; pe- }}$ \\
\hline$" \quad$ June 26 & $\begin{array}{l}\text { M. } 5: \\
(2 \cdot 20)\end{array}$ & $\begin{array}{l}\text { Lithate of am. } \\
\text { monis, } 105 \\
\text { grs.; } 4 \text { years }\end{array}$ & Sept. 20. Cured \\
\hline
\end{tabular}

Note. In addition to the former Statistical Report (Transactions, vol. xix.)

Case. A girl, aged 12 years, underwent operation in March 1838, in whom symptoms had existed for six years, at times with great suffering and considerable cmaciation. Although it was known that there was a stone in the bladber, her mother resisted the performance of any operationperhaps from the case exciting the attention of charitable persons. The child had been admitted into the infirmary when seven years old, and it was hoped that dilatation might be then effected; but her unmanageable temper and the interference of the mother hindered anything being done. Upon her being admitted a second time, a dose of laudanum (forty minims) was given, which, in about an hour produced considerable coma, and she was barely conscious when placed on the table. In this state the operation was performed without trouble. The calculus weighed seven drachms, and was composed of oxalate of lime, with a thick coating of phosphates. (3.)

Oxford, April 1865,

\section{THE BREATHING AND THE PULSE UNDER} THE INFLUENCE OF CHLOROFORM.

By JOHN SNOW, M.D., President of the Medical Society of London.

Ir seems physically impossible that the breathing should not be noticed during the administration of narcotic rapours, for it is by the breath that they are exhibited; and it is extremely improbable that the state of the respiration has ever been disregarded. Even a stranger to medicine could hardly go on giving chloroform after the breathing of the patient became stertorous and labourod, especially as a state of complete insensibility always accompanies this kind of breathing. In treating of sulphuric ether in $1847_{r}$ I made the remark that, "if there is the least snoring, I always leave off the vapour entirely"; * and, in treating of chloroform, I have always stated that the inhalation should be suspended whenever the breathing becomes stertorous. In doing so, however, I never supposed that I was propounding anything new; I looked on the matter as one of those truisms that every one would at once assent to, but which could not with propriety be omitted in treating systematically of the subject.

I have always considered the pulse amongst the secondary symptoms in administering chloroform, not because any serious affection of the pulse would be a trifling matter, but because the vapour should be so given that it would be im. possible for it to exert any serious effect on the pulse. After stating, in a paper written four or five years ago, that the most important point in giving chloroform is to take care that its vapour is systematically diluted with a sufficient quantity of air, I mid that, the above precaution having been taken, "it is chiefly by attention to the respiration and the eye that danger is to be aroided"; and I 